\title{
Influence of Certain Animal Manures on Nematode Community in Mandarin Orchards Citrus reticulata (Blanco) in Sharkia Governorate, Egypt
}

\author{
El-Marzoky A. M.; Eldeeb A. M.; Mahrous M. E. and El-Ashry R. M. \\ Plant Prot. Dept., Fac. Agric., Zagazig University, Egypt \\ E-mail: amr elmarzoki@yahoo.com
}

\begin{abstract}
The effects of cow, horse and turkey manures in comparison with oxamyl on phytoparasitic, free-living and predacious nematodes were verified in a mandarin orchard located in Sharkia Governorate during 2017. Treatments of cow and horse manures were at the rate of 6.4 tons/ feddan, while that of turkey manure was at the rate of 4.8 tons/ feddan. However, oxamyl $10 \% \mathrm{G}$ was treated at the rate of $25 \mathrm{~kg}$ / feddan. Samples were taken monthly during three months after application. Soil temperature and $\mathrm{pH}$ were measured after sampling. Results indicated that the tested manures and oxamyl significantly $(\mathrm{P} \leq 0.05)$ minified numbers of phytonematodes. The best treatment (after oxamyl) was turkey manure followed by horse manure, while cow manure was the least effective one. Remarkable decrease in numbers of plant-parasitic nematodes was noticed as the time elapsed after application. For instances, in turkey manure treatment percentages reduction in numbers of Tylenchulus semipenetrans, Pratylenchus spp., Tylenchorhynchus spp., and Helicotylenchus spp. after 2 and 3 months were diminished by 56.78\% (75.29\%), $57.66 \%$ (78.54\%), 56.84\% (77.95\%) 56.23\% and (78.28\%), respectively. On the other hand, one month after application, the tested manures slightly increased numbers of free-living nematodes mainly genus Rhabditis and predacious nematodes belonging to order: Mononchida. Whereas, 2 and 3 months after application pronounced abundance of these nematodes was detected. The highest augmentation was achieved in soil amended with turkey manure. However, oxamyl decreased numbers of nonstomatostylet bearing nematodes compared to untreated trees. The tested manures raised soil temperature and altered soil $\mathrm{pH}$ to be alkaline. Generally, our results emphasized the significance of animal manures particularly the turkey one in suppression plant-parasitic nematodes in mandarin orchards which may be attributed to its role in increasing predacious nematodes and change soil temperature and $\mathrm{pH}$.
\end{abstract}

Keywords: Animal manures, control, Tylenchulus semipenetrans, mandarin, freeliving nematodes, predacious nematodes, soil temperature, soil $\mathrm{pH}$.

\section{INTRODUCTION}

The mandarin, Citrus reticulata (Blanco) cultivation had a great importance to production and exportation among all the citrus cultivars all over the world. Egypt had ranked fifth around the world in mandarin production, which was at 917404 tons in 
2016 and it formed about 3.2\% of the world production (FAO, 2016). In Egypt, previous nematological surveys carried out in mandarin orchards have shown the occurrence of many phytoparasitic nematodes, i.e. Tylenchulus semipenetrans, Pratylenchus spp., Helicotylenchus spp., Tylenchorhynchus spp., Meloidogyne spp., Xiphinema spp. and Trichodorus spp. (Mahrous et al., 1985; El-Marzoky et al., 2009 and Ibrahim et al., 2016). Among which, T. semipenetrans was reported to cause remarkable damage to citrus trees (Abou-El-Naga et al., 1984; Bakr et al., 2011 and Montasser et al., 2012). The annual economic losses in crop yield due to infestation with citrus nematode were ranged from 8.7 to $12.2 \%$, according to Cohn (1972) and $14 \%$ according to Sasser (1989).

Chemical nematicides have been applied widely to control plant-parasitic nematodes with fast-acting and considerable results. However, they are both expensive and environmentally unfriendly method. Since there are many reports concerned with contamination of ground water and different food types with nematicides. For example, concentration of aldicarb residues exceeded the reference doses in orange fruits in Sharkia governorate (Tchounwou et al., 2002). On the other hand, Egyptian citrus exports are facing severe competition with Mediterranean countries. The main problem in this respect is the extensive use of chemical fertilizers and pesticides that are not accepted by the European markets (Bazargan, 2017). All these factors enhanced nematologists to search for another alternative safe and low costing methods to manage plant-parasitic nematodes in citrus orchards. Therefore, the main objective of this study was to verify the effect of the three animal manures i.e. cow, horse and turkey in comparison with oxamyl on parasitic and beneficial nematodes in a mandarin orchard at Sharkia governorate. It is necessary to mention that, the term manure in this study refers to wastes from livestock (including cow, horse and turkey), usually mixed with bedding such as sawdust, rice strain and feed waste.

This pollution can directly affect plants or indirectly by contaminating the groundwater of these plants with chemical nematicides (Jones \& Back, 1983 and Wixted et al., 1987). The organic farms have been increased significantly in the world over the last several years and are expected to grow in the future. Organic amendments especially, animal manures are used as an effective alternative, relatively inexpensive and eco-friendly methods for reducing nematode populations (ElMarzoky, 2009 \& 2015).

The addition of animal manures improves soil structure, supplied plants with nutrient elements like nitrogen, potassium, and phosphorus through its decomposition, and can stimulate natural enemies. The organic manures were shown to be rich in nitrogen and phenolic compounds (Renco \&Kovácik, 2012). In addition, in decomposition process of these materials, nitrogen converted to ammonia (Oka, 2010 and Thoden et al., 2011). Therefore, many authors suggested using animal manures, i.e., poultry, pigeon, horse, sheep and duck dung in the programs of controlling phytonematodes (Kimenju et al., 2004). Generally, this study aims to show the role of animal manures in biological control of phytonematodes infesting mandarin orchards by increasing predacious and free-living nematodes and inducing changes in certain soil properties like temperature and $\mathrm{pH}$. 


\section{MATERIALS AND METHODS}

\section{Experimental site:}

This experiment was carried out in a Balady mandarin orchard, cultivated with 15years old trees grafted on sour orange rootstock (Citrus aurantium), spaced at $4 \mathrm{~m}$ apart and located in Basateen Serag El-Dein locality, Belbies district, Sharkia Governorate. The experimental area was characterized by sandy soil $(71.80 \%$ sand, $15.75 \%$ clay and $12.15 \%$ silt), with surface irrigation system.

2. Effect of the certain animal manures on population density of nematode species in the soil:

Organic animal manures were regularly applied to the soil during the growing season of a given crop. On the other hand, one of the alternative strategies for plant-parasitic nematode management is the application of organic manures. Therefore, three animal manures namely, cow, horse and turkey manures in comparison with the nematicide oxamyl were evaluated in suppressing populations of plant parasitic nematodes in the selected mandarin orchard. The tested manures were collected from three different clean organic farms situated in Belbies district, while oxamyl was obtained from Plant Protection Research Institute, Dokki, Giza. Based on certain literature reports, the nitrogen contents in cow, horse and turkey manures were 17700, 19500 and 29100 ppm, respectively (El-Marzoky, 2009 and Sideman et al. 2013). Accordingly, cow and horse manures were applied at the rate of $40 \mathrm{~kg} /$ tree $(6.64$ tons/ feddan), whereas the turkey manure was added at the rate of $30 \mathrm{~kg} /$ tree (4.98 tons/ feddan). Moreover, the chemical nematicide oxamyl (Vydate 10\% G), Methyl 2-(dimethylamino)-N[(methylcarbamoyl) oxy]-2-oxoethanimidothioate was treated at $150 \mathrm{~g} /$ tree (25 $\mathrm{kg} /$ feddan). A complete randomized block design with three replicates was followed. The experimental site was divided into five plots (rows), each plot contains 10 trees. The selected rows were separated from each other by one parallel row. Three trees in each row were chosen randomly, labelled and served as replicates for the treatments. Animal manures were air dried for three weeks before use. Manures and oxamyl were separately incorporated in the top $10-20 \mathrm{~cm}$ of the soil layer in the canopy of the treated trees. Trees of the control treatment were left without any amendments or chemical nematicide. Three subsamples were taken at $20-25 \mathrm{~cm}$ depth, under tree canopy with a hand trowel after one, two and three months of application during the period from January to April 2017. The three subsamples were mixed to form a composite sample of about $1 \mathrm{~kg}$, kept in polyethylene bags and sent directly to the laboratory. An aliquot sample of $250 \mathrm{~g}$ soil was processed for nematode extraction. Nematodes were extracted using a combination of serving and Baermann trays technique (Hopper et al., 2005). For nematode identification, $1 \mathrm{ml}$ of nematode suspension was pipetted into Hawksely counting slide and nematodes were examined by the aid of the of research microscope under 100X magnification. Based on morphology of adult and juvenile forms nematodes were identified according to Mai and Lyon (1975) and Siddiqi (1986).

The nematode reduction (\%) was calculated according to the following equation:

$$
\text { Nematode reduction }(\%)=\frac{\text { Control }- \text { treatment }}{\text { Control }} \times 100
$$


3. Effect of applied treatments on soil temperature and $\mathrm{pH}$ :

It was evident that soil temperature was the most essential factor affecting nematode communities (Morris et al., 2011). Therefore, changes in the two factors were measured at 0,1,2 and 3 months of applying the tested amendments. Soil temperature was detected with a soil thermometer. A screwdriver was used to make a pilot hole to a depth of $20 \mathrm{~cm}$ in top layer of the soil under the canopy of trees. The thermometer was inserted into the hole for about one minute. If the sun was bright the thermometer was shaded by the hand to keep readings accurate. Two readings were taken during five consecutive days after nematode sampling every month. The two readings were taken in the morning and late afternoon. The average of two readings was recorded. The same procedures were accomplished under trees of control treatment. Days of extremes in temperature and rainfall were avoided (Julie, 2011).

Soil $\mathrm{pH}$ was detected using a digital $\mathrm{pH}$ meter. A hand trowel was used to collect three subsamples from $20-30 \mathrm{~cm}$ layer under the canopy of each tree replicate. The subsamples were carefully mixed and stones or plant debris were removed. Aliquot sample of about $100 \mathrm{~g}$ of the mixed soil were placed in a clean $300 \mathrm{ml}$ plastic beaker. Distilled water was added to the soil until it was damp enough. The probe of the digital $\mathrm{pH}$ meter was cleaned and inserted into the soil and the device was turned on. The probe was twisted to make sure that it had a good contact with the soil and did not contact the bottom of the beaker. It was left in the soil to about one minute until the reading stabilized and then the reads were recorded at the time of application and at monthly intervals (Hamilton, 2013).

\section{RESULTS AND DISCUSSION}

\section{Impact of three animal manures on phytonematodes infesting mandarin orchard:}

Preliminary samples were collected from a chosen mandarin orchard before experimentation. Morphological identification of adult and juvenile forms revealed the occurrence of the citrus nematodes, Tylenchulus semipenetrans Cobb; the lesion nematodes, Pratylenchus spp. Flipjev; the stunt nematodes, Tylenchorhynchus spp. Cobb and the spiral nematodes, Helicotylenchus spp. Steiner.

Data in Table (1) show the effect of the three animal manures, i.e., cow, horse and turkey manures compared to oxamyl on plant- parasitic nematodes after one month of application. It was found that, all treatments significantly $(\mathrm{P} \leq 0.05)$ reduced numbers of $T$. semipenetrans compared to check treatment. Oxamyl surpassed all applications with insignificant variations with turkey manure. On the other hand, slightly insignificant differences were detected between the three manures under investigation treatments when they were compared with each other. However, plots treated with oxamyl overwhelmed those amended with cow manure or horse manure in minimizing numbers of $T$. semipenetrans. Percentages reduction in descending order for oxamyl, turkey manure, horse manure and cow manure were 45.28, 32.27, 28.58 and $19.55 \%$ consecutively.In respect to efficiency of the tested materials on other phytonematodes, results in Table (1) clearly showed that oxamyl, turkey manure and horse manure significantly $(\mathrm{P} \leq 0.05)$ minified numbers of Pratylenchus spp., Tylenchorhynchus spp. and Helicotylenchus spp. compared to control treatment. However, cow manure achieved the lowest insignificantly effect. Ranges of percentages reduction in populations of Pratylenchus spp., Tylenchorhynchus spp. and 
Table 1. Effect of three animal manures and oxamyl on plant parasitic nematodes infesting mandarin orchard, one month after application.

\begin{tabular}{|l|c|c|c|c|}
\hline \multirow{4}{*}{ Treatment } & \multicolumn{4}{|c|}{ Nematode populations per 250 g soil } \\
\cline { 2 - 5 } & T. semipenetrans & $\begin{array}{c}\text { Pratylenchus } \\
\text { spp. }\end{array}$ & $\begin{array}{c}\text { Tylenchorhynchus } \\
\text { spp. }\end{array}$ & $\begin{array}{c}\text { Helicotylenchus } \\
\text { spp. }\end{array}$ \\
\hline Control & $3540 \mathrm{a}^{*}$ & $45.0 \mathrm{a}$ & $36.3 \mathrm{a}$ & $31.0 \mathrm{a}$ \\
& $(0)$ & $(0)$ & $(0)$ & $(0)$ \\
\hline Oxamyl & $1937.0 \mathrm{c}$ & $25.7 \mathrm{~b}$ & $15.3 \mathrm{~b}$ & $14.3 \mathrm{~b}$ \\
& $(45.28)$ & $(42.95)$ & $(57.80)$ & $(54.77)$ \\
\hline Cow manure & $2847.7 \mathrm{~b}$ & $35.0 \mathrm{ab}$ & $25.7 \mathrm{ab}$ & $21.7 \mathrm{ab}$ \\
& $(19.55)$ & $(22.22)$ & $(29.36)$ & $(30.09)$ \\
\hline Horse manure & $2528.3 \mathrm{~b}$ & $27.7 \mathrm{~b}$ & $23.3 \mathrm{~b}$ & $15.7 \mathrm{~b}$ \\
& $(28.58)$ & $(38.51)$ & $(35.78)$ & $(49.45)$ \\
\hline Turkey manure & $2397.3 \mathrm{bc}$ & $23.7 \mathrm{~b}$ & $18.7 \mathrm{~b}$ & $15.7 \mathrm{~b}$ \\
& $(32.27)$ & $(47.4)$ & $(48.60)$ & $(49.45)$ \\
\hline
\end{tabular}

* Each value is a mean of 3 replicates.

$*$ Values in brackets indicate $\%$ reduction $=\underline{\text { Control- Treatment }} \times 100$

Control

* Means in each column followed by the same letter(s) are not significantly different at $\mathrm{P} \leq 0.05$ according to Duncan's multiple range test.

.Helicotylenchus spp. for tested materials were 22.22 to $47.40 \%, 29.36$ to $57.80 \%$ and 30.09 to $54.77 \%$, respectively.

Data in Tables 2 and 3 illustrate the population densities and percent reductions of phytonematodes in due to the application of the tested treatments compared to the untreated control at 2 and 3 months after application. Similarity, oxamyl proved to be the most suppressive one, which recorded 65.86 and $95.33 \%$ reduction in numbers of T. semipenetrans after 2 and 3 months of application, respectively

Moreover, it attained 78.30, 70.52 and $75.00 \%$ reduction in numbers of Pratylenchus spp., Tylenchorhynchus spp. and Helicotylenchus spp., successively after two months. These values were obviously increased to $92.20,97.24$ and $98.48 \%$ respectively, after three months of application.

It worth mentioning that, among the applied manures, turkey one sustained the best results in prohibiting numbers of $T$. semipenetrans with no significant difference with oxamyl treatment. It was followed descendingly by horse manure and cow manure with the same ability to inhibit numbers of citrus nematode. Percentages reduction in numbers of $T$. semipenetrans after two months of application for turkey manure, horse manure and cow manure were 56.78, 43.22 and $39.37 \%$ consequently. However, these values were markedly increased to 75.29, 67.14 and 55.39\% correspondingly, after three months of application.

Regarding effects of animal manures, on the genera, Pratylenchus, Tylenchorhynchus and Helicotylenchus it was clear that all the tested animal manures, significantly decreased their numbers after 2 and 3 months of application. In all cases remarkable decrease in numbers of these genera was noticed as the time elapsed from second to third month after application. 
Table 2. Effect of three animal manures and oxamyl on plant parasitic nematodes infesting mandarin orchard, two months after application.

\begin{tabular}{|l|c|c|c|c|}
\hline \multirow{2}{*}{ Treatment } & \multicolumn{4}{|c|}{ Nematode populations per 250 g soil } \\
\cline { 2 - 5 } & T. semipenetrans & $\begin{array}{c}\text { Pratylenchus } \\
\text { spp. }\end{array}$ & $\begin{array}{c}\text { Tylenchorhynchus } \\
\text { spp. }\end{array}$ & $\begin{array}{c}\text { Helicotylenchus } \\
\text { spp. }\end{array}$ \\
\hline Oxamyl & $3639.3 \mathrm{a} *$ & $63.0 \mathrm{a}$ & $63.3 \mathrm{a}$ & $42.7 \mathrm{a}$ \\
& $(0)$ & $(0)$ & $(0)$ & $(0)$ \\
\hline Cow manure & $1242.3 \mathrm{c}$ & $13.7 \mathrm{c}$ & $18.7 \mathrm{c}$ & $10.7 \mathrm{c}$ \\
& $(65.86)$ & $(78.30)$ & $(70.52)$ & $(75.00)$ \\
\hline Horse manure & $2206.33 \mathrm{~b}$ & $38.7 \mathrm{~b}$ & $40.3 \mathrm{~b}$ & $25.7 \mathrm{~b}$ \\
& $(39.37)$ & $(38.61)$ & $(36.32)$ & $(39.82)$ \\
\hline Turkey manure & $2066.3 \mathrm{~b}$ & $37.0 \mathrm{bc}$ & $36.0 \mathrm{bc}$ & $22.0 \mathrm{bc}$ \\
& $(43.22)$ & $(41.27)$ & $(43.15)$ & $(48.42)$ \\
\hline
\end{tabular}

* Each value is a mean of 3 replicates.

* Values in brackets indicate $\%$ reduction $=\underline{\text { Control- Treatment }} \times 100$ Control

* Means in each column followed by the same letter(s) are not significantly different at $\mathrm{P} \leq 0.05$ according to Duncan's multiple range test.

Table 3. Effect of three animal manures and oxamyl on plant parasitic nematodes infesting mandarin orchard, three months after application.

\begin{tabular}{|l|c|c|c|c|}
\hline \multirow{3}{*}{ Treatment } & \multicolumn{4}{|c|}{ Nematode populations per 250 g soil } \\
\cline { 2 - 5 } & T. semipenetrans & $\begin{array}{c}\text { Pratylenchus } \\
\text { spp. }\end{array}$ & $\begin{array}{c}\text { Tylenchorhynchus } \\
\text { spp. }\end{array}$ & $\begin{array}{c}\text { Helicotylenchus } \\
\text { spp. }\end{array}$ \\
\hline Oxamtrol & $3334.3 \mathrm{a}$ & $119.7 \mathrm{a}$ & $96.7 \mathrm{a}$ & $66.0 \mathrm{a}$ \\
& $(0)$ & $(0)$ & $(0)$ & $(0)$ \\
\hline Cow manure & $155.7 \mathrm{c}$ & $9.3 \mathrm{c}$ & $2.7 \mathrm{c}$ & $1.0 \mathrm{c}$ \\
& $(95.33)$ & $(92.20)$ & $(97.24)$ & $(98.48)$ \\
\hline Horse manure & $1487.3 \mathrm{~b}$ & $50.7 \mathrm{bc}$ & $45.3 \mathrm{bc}$ & $30.7 \mathrm{bc}$ \\
& $(55.39)$ & $(57.65)$ & $(53.10)$ & $(53.53)$ \\
\hline Turkey manure & $1095.7 \mathrm{~b}$ & $40.3 \mathrm{bc}$ & $34.7 \mathrm{bc}$ & $20.7 \mathrm{bc}$ \\
& $(67.14)$ & $(66.29)$ & $(64.14)$ & $(68.68)$ \\
\hline
\end{tabular}

* Each value is a mean of 3 replicates.

$*$ Values in brackets indicate $\%$ reduction $=\underline{\text { Control- Treatment }} \times 100$ Control

* Means in each column followed by the same letter(s) are not significantly different at $\mathrm{P} \leq 0.05$ according to Duncan's multiple range test. 
For instances, in turkey manure treatment numbers of Pratylenchus, Tylenchorhynchus and Helicotylenchus, after 2 and 3 months of application were 26.7 (25.7), 27.3 (21.3) and 18.7 (14.3) individuals per $250 \mathrm{~g}$ soil, respectively. Likewise, the respective values in cow manure treatment were 38.7 (50.7), 40.3 (45.3) and 25.7 (30.7) individuals per $250 \mathrm{~g}$ soil. Generally, it could be concluded that, turkey manure was the best treatment (after the nematicide) in suppressing numbers of phytonematodes infesting mandarin trees, followed by horse manure and cow manure was the least effective one in this respect.

Results of current study indicated that the tested treatments exhibited a considerable nematicidial activity and significantly minified populations of plantparasitic nematodes. Oxamyl proved to be the most suppressive one. Whereas, among the tested manures, turkey one was the best treatment followed by horse manure while cow manure was the least effective one. Remarkable reduction in numbers of plantparasitic nematodes was detected as the time elapsed from first to second and third months after application. These results are in agreement with those reported by many authors who tested organic manures against T semipenetrans (Badra et al., 1979 and Montasser et al., 2012), Pratylenchus (Yang et al., 2016) and Helicotylenchus, Tylenchorhynchus (Rodriguez- Kabana, 1986). Conversely, Kimpinski et al., (2003) showed that compost and manure treatments increase numbers of $P$. penetrans in potato soil due to increase in soil moisture and better development of potato roots which provided more recourses for nematode populations. These amendments did not affect Meloidogyne hapla population density in amended plots. However, Heterodera trifolii was more pronounced in root-zone soil of barley treated with compost. Moreover, McSorley \& Gallaher (1996) found that yard-waste compost did not affect Pratylenchus spp. On the other hand, Whitehead (1998) showed that even when organic amendments appear to have negative effect on plant parasitic nematodes, the large amount needed for effective control make their use feasible only in small areas.

The effectiveness of organic amendments depends on their nitrogen content and $\mathrm{C} / \mathrm{N}$ ratio. Fertilizers with high nitrogen content are more effective than those with low values. Our results in this study support this fact, since turkey manure contained a relatively higher values of nitrogen $(29100 \mathrm{ppm})$ compared to horse $(19500 \mathrm{ppm})$ and cow (17700 ppm) manures ( El-Marzoky, 2009 and Sideman et al., 2013). Moreover, materials with narrower $\mathrm{C} / \mathrm{N}$ ratio were more effective than those with broader $\mathrm{C} / \mathrm{N}$ ratio. Apparently, $\mathrm{C} / \mathrm{N}$ ratio of 15-20 are the optimal to the soil microorganisms when amendments are added to 1\% level (Main\& Rodriguez- Kabana, 1982 and Osunlola \&Fawole, 2015).

The nematicidal effect of organic manures on plant parasitic nematodes could be attributed to many factors. Among which direct effects of chemicals produced during manure decomposition such as ammonia, hydrogen sulphide ,methan, fatty acids with low molecular weight like acetic, propionic acids, dimethlamine , trimethyamine as well as phenols. All these materials were reported to be deleterious to different species of plant-parasitic nematodes ( Badra et al., 1979 ; Main \& Rodriguez -Kabana, 1982; Rodriguez-Kabana, 1986; Kesba \&Al-Shalaby, 2008 and Nowak et al., 2017).

Another mechanism involved in suppression effect of animal manures is related to role of microorganisms. Since, it has been suggested that soil amendments 
encourage and enhance microbial populations that exhibit antagonistic action against plant-parasitic nematodes either as direct parasites or predators or by their metabolites produced during their activities (Riegel \&Noe, 2000; Akhtar \& Malik, 2000 and Oka, 2010). Also, three species of nematophagous fungi were isolated from poultry, horse, pig and carabao dungs (Castillo, 1985). Furthermore, antagonistic fungi have been isolated from juveniles and egg masses of nematodes in organic soil in New York (Viaene \& Abawi, 1998). Additionally, the reduction of plant-parasitic nematode populations could also due to changes in soil physical and chemical conditions, besides physiological changes in roots which make the plants more tolerant or resistance against nematodes (Osunlola and Fawole, 2015).

\section{Influence of the tested animal manures on numbers of free-living and predacious nematodes:}

Data presented in Fig.1 show behavior of free-living and predacious nematode populations after 1, 2 and 3 months of applying the three animal manures viz. cow, horse and turkey manures and the nematicide oxamyl. One month after application number of free living nematodes mainly genus Rhabditis and predacious nematodes belonging to order: Mononchida were slightly increased compared to a relatively lower values in oxamyl and control treatments. Between the tested fertilizers turkey manure gave the highest increase followed by horse manure while cow manure was the lowest effective one. On the other hand, oxamyl minified numbers of non-stylet bearing nematodes when it was compared to untreated check. Population density of free living and predacious nematodes per $250 \mathrm{~g}$ soil in plots treated with turkey manure, horse manure and cow manure were 81.7 (65.0), 66.3 (63.3) and 49.7 (46.3) individuals in $250 \mathrm{~g}$ soil, respectively. The respective values in oxamyl and control treatment were 35.3 (22.7) and37.3 (33.0) individuals, respectively.

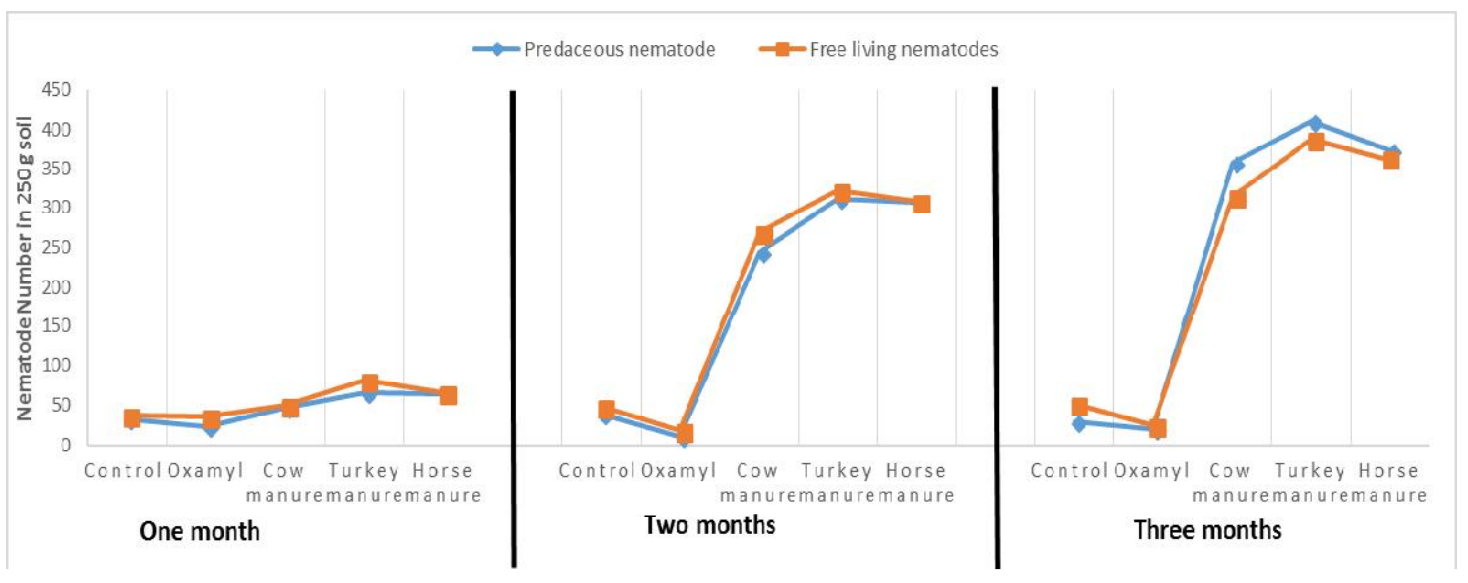

Fig. 1. The effect of animal manures and oxamyl on predaceous and free-living nematodes after, one, two and three months of treatment.

Two and three months after application, pronounced increase in numbers of free-living and predacious nematodes were detected in treatments of animal manures. The highest augmentation was achieved in plots amended with turkey manure, followed in descending order by those amended with horse manure and cow manure. Numbers of free living and predacious nematodes per $250 \mathrm{~g}$ soil in turkey manure treatment at 2 and 3 months post treatment were 321.7 (310.7) and 388.3(410.7) 
nematodes / $250 \mathrm{~g}$ soil, respectively, versus to 19.0 ( 10.3$)$ and 25.0 ( 20.0 ) nematodes/ $250 \mathrm{~g}$ soil in oxamyl treatment, respectively, while the respective values in control treatment were 48.3 (50.7) and 39.0 (29.0) nematode/ $250 \mathrm{~g}$ soil, consecutively. Likewise, similar situations occurred in treatments of horse and cow manures.

Irrespective to the effect of the tested manures on free- living and predatory nematodes, results showed that one month after application, numbers of free- living nematodes mainly genus Rhabditis and predatory nematodes belonging to order: Mononchida were slightly increased compared to oxamyl and control treatments. However, after two and three months pronounced increase in numbers of free-living and predatory nematodes were detected. This is consistent with findings of Akhtar \& Malik (2000) ; Kimpinski et al. (2003) ; El-Marzoky (2015) and Yang et al. (2016).

\section{The effect of animal manures on the soil temperature and $\mathrm{pH}$.}

To assess the efficiency of certain soil parameters on numbers of phytonematodes, soil temperature and $\mathrm{pH}$ were measured at monthly intervals during study period. Results in Fig.2 clearly indicated that amending mandarin with animal manures raised soil temperature. One month after treatment, soil temperature in plots received turkey, horse and cow manures were $28.6,27.6$ and $26.4^{\circ} \mathrm{C}$ respectively, in comparison to control and oxamyl treatments which were 23.6 and $22.8^{\circ} \mathrm{C}$ consequently. Similar results were obtained after 2 and 3 months of treatment. For instance, turkey, horse and cow manures were capable of raising soil temperature after 2 and 3 months to 30.6 (32.4), 29.3 (31.2) and $27.2(30.6){ }^{\circ} \mathrm{C}$, respectively in relation to check treatment which achieved 19.8 and $27.4{ }^{\circ} \mathrm{C}$, consequently.

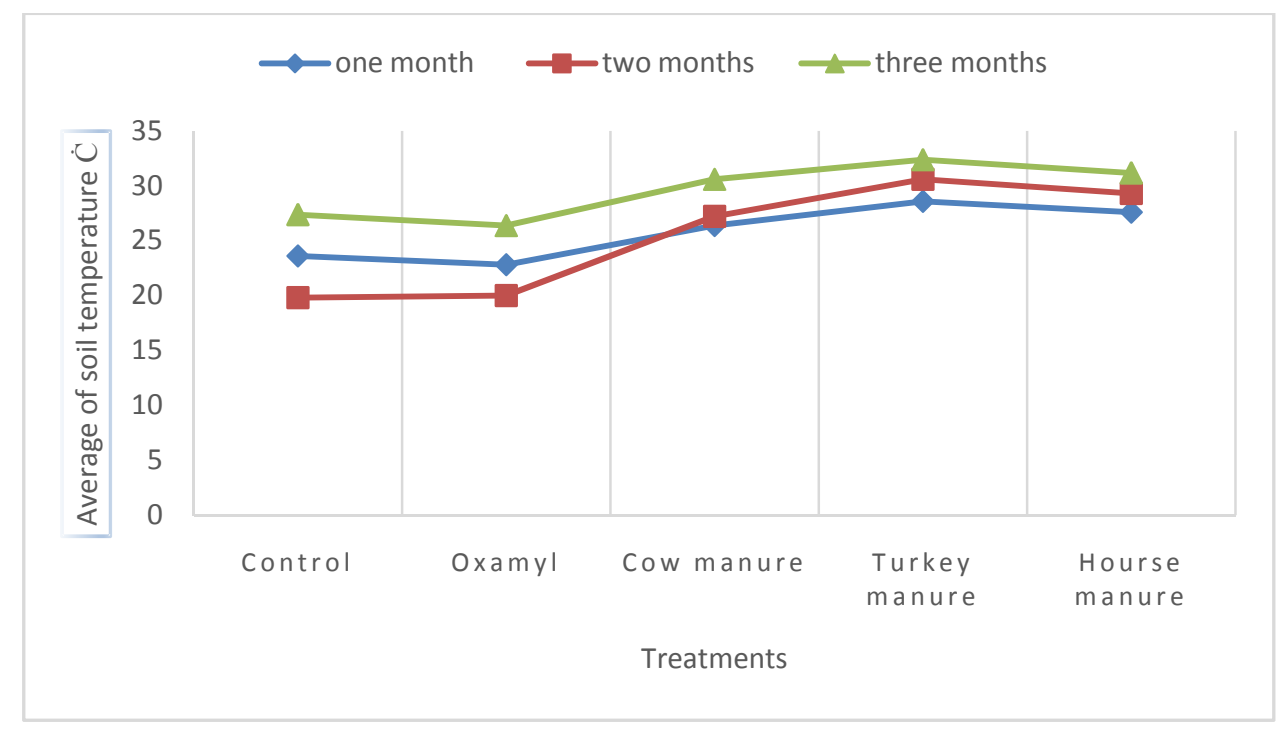

Fig. 2. The effect of applying animal manures on the soil temperatures after one, two and three months of treatment

Soil $\mathrm{pH}$ was changed as a result of utilization animal manures. Results in Fig. 3 showed that soil $\mathrm{pH}$ was altered toward to be alkaline after adding animal manures. After one month, soil $\mathrm{pH}$ in treatments of turkey, horse and cow manures were 6.8, 6.5 and 6.3, respectively compared to treatments of oxamyl and control which were 5.1 and 5.2, successively. However, these values were increased after two and three 
months of treatment to reach $7.2(8.2), 7.1(8.0)$ and $6.8(7.8)$ in soil amended with turkey, horse and cow manures, respectively while the parallel values in oxamyl and control treatment were 5.2 (5.2) and 5.1(5.2), correspondingly.

Our results showed that $\mathrm{pH}$ of soil amended with animal manures was altered toward to be alkaline and it may be responsible for remarkable reduction of plantparasitic nematodes. This finding is in accordance with Oka (2010) and Yang et al. (2016) who showed that increasing soil $\mathrm{pH}$ from acidity to neutral or alkaline effectively reduced numbers of plant-parasitic nematodes.

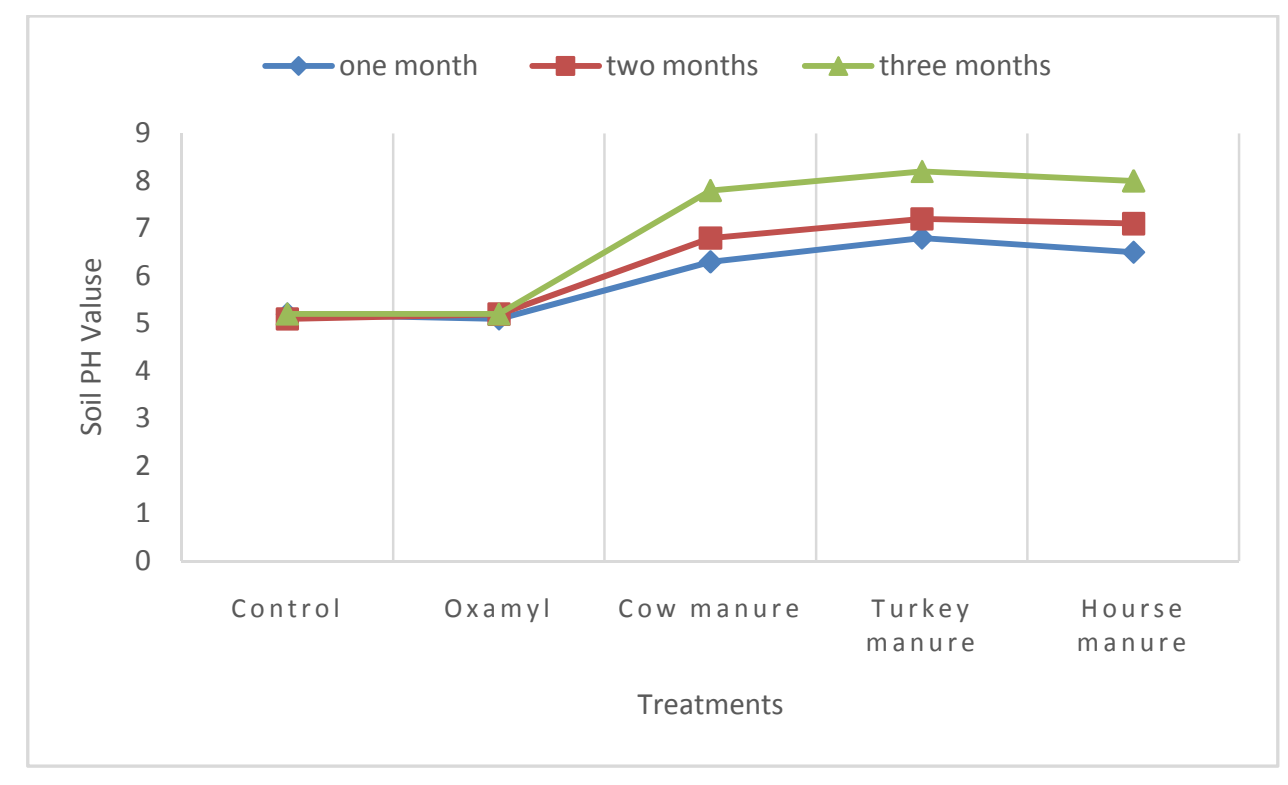

Fig. 3. The effect of applying animal manures on the soil $\mathrm{pH}$ after one, two and three months of treatment.

In contrary, Kaplan and Noe (1993) reported that reduction of M. arenaria populations in soil amended with chicken-excrement may be due to lowering of $\mathrm{pH}$ due to addition of ammonia. In this respect, many authors indicated that fertilizers contained ammonical nitrogen are more destructive to parasitic nematodes than those contained nitrate nitrogen (Badra et al., 1979). Moreover, during decomposition process of organic manures nitrogen converted to ammonia, that kill plant -parasitic nematodes (Oka, 2010 and Thoden et al., 2011). Regarding the role of animal manures in increasing soil temperature and consequently affect nematode community, there are no literature reports concerning this subject. However, our results revealed that the tested animal manures increased soil temperature, compared to control treatment and it may be one of the mechanisms involved in suppression effects of animal manures especially during summer months.

Generally, results of this study suggest the possibility of using animal manures i.e cow, horse and turkey at rate of 40,40 and $30 \mathrm{~kg} /$ tree, respectively in to reducing plant parasitic nematodes and increasing beneficial nematodes in mandarin orchards. This method of nematode control is less expensive, safe and improve soil structure and fertility. Further investigation is needed to identify microorganisms responsible in suppressing populations of plant parasitic nematodes.

\section{REFERENCES}


Abou-El-Naga, M.M.; Metwaly, A.M. and Montasser, S.A. (1984). New records of nematodes associated with citrus fields in Egypt. Agri. Res. Rev. 62: 271-275.

Akhtar, M. and Malik, A. (2000). Roles of organic soil amendments and soil organisms in the biological control of plant-parasitic nematodes. A review Bioresour. Technol. 74: 35-47.

Badra, T.; Salem, M.A. and Oteifa, B.A. (1979). Nematicidal activity of some organic fertilizers and soil amendments. Revue de Nematol. 2(1) :29-36.

Bakr, R.A.; Mahdy, M.E; Mousa, E.M. (2011). A survey of root-knot and citrus nematode in some new reclaimed land in Egypt. Paki. J. Nematol. 29: 165170 .

Bazargan, K. (2017). Potential hazards of pesticides, fertilizers in farm food. https://financialtribune.com/articles/people/62433/.

Castillo, M. B. (1985). Some studies on the use of organic soil amendments for nematode control. Philippine Agricultural Scientist 68: 76-93.

Cohn, E. (1972). Nematode diseases of citrus. Pp 215-244, In: Economic Nematology, Ed: J.M. Webster, Academic Press, London., 563 pp.

El-Marzoky, A.M. (2009). Studies on phytonematodes infecting citrus in reclaimed areas of Sharkia Governorate. M.Sc. Thesis, Fac. Agric., Zagazig Univ. 123 pp.

El-Marzoky, A.M. (2015). Ecological and control studies on nematodes infecting grapes in Sharkia Governorate. Ph.D. Thesis, Fac. Agric., Zagazig Univ. 126 pp.

El-Marzoky, A.M.; Salem, A.A.; Mahrous, M.E. and Basha, A.E. (2009). Plant parasitic nematodes infesting citrus orchards in Sharkia Governorate, East Delta, Egypt, with special reference to Tylenchulus semipenetrans Cobb. Zagazig J.Agric. Res. 36(1): 195-211.

FAO (2016). The Mandarin Production by the Food and Agriculture Organization of the United Nations 200-205.

Hamilton, P. (2013). http://homeguides.sfgate.com/test-soil-ph-digital-ph-meter 71906.html.

Hopper, D.J.; Hallmann, J. and Subbotin, S.A. (2005). Methods of extraction, processing and detection of plant soil nematodes. Pp 53-84. In: Plant parasitic nematodes in subtropical and tropical agriculture. Luc M.; Sikora A.R. and Bridge J., 2 Edn. CAB International, Wallingford, UK.

Ibrahim, I.K.I and Mokbel, A.A. and Hando, Z. (2016).Current status of phytoparastic nematodes and their host plants in Egypt. Nematropica 40 (2): 239-262.

Jones, R. and Back, R.C. (1983). Monitoring aldicarb residues in Florida soil and water. Environmental Toxicology and Chemistry 2: 269-281.

Julie, D. (2011). How to measure soil temperature for planting. https:// www. todayshomeowner.com/

Kaplan, M. and Noe, J. (1993). Effect of chicken- excrement amendments on Meloidogyne arenaria. J. Nematol. 25(1): 71-77.

Kesba, H. H. and Al-Shalaby Mona, E. M. (2008). Survival and reproduction of Meloidogyne incognita on tomato as affected by humic acid. Nematology 10 : 243-249. 
Kimenju, J.W.; Muiru, D.M.; Karanja, W.M.; Nyongesa, W.M.; Miano D.W. and Mutua, G.K. (2004). Assessing the role of organic soil amendments in the management of root-knot nematode on common bean, Phaseolus vulgaris L. J. Tropic. Microbiol. 3(1): 14-23.

Kimpinski, J.; Gallant, I.C.E.; Henry, I.R.; Macleod, I.J.A; Sanderson, I. and Sturz, A.V.C. (2003). Effect of compost and manure as soil amendments on nematodes and on yield of potato and barley. A 7- year study. J. Nematol. 35(3): 289-293.

Mahrous, M.E.; Abo El-Naga, M.M.; Montasser, S.A. and Lokma, H.E. (1985). Plant parasitic nematodes associated with certain crops under different irrigation systems at Khattara project, newly reclaimed area, Egypt Zagazig J. Agric. Res. 12 (1): 707-723.

Mai, W.F. and Lyon, H.H. (1975). Pectoral key to genera of plant parasitic nematodes. Cornell Univ. Press, Ithaca, New York, 219 pp.

Mankau, R. (1963). Effect of organic soil amendments on nematode populations. Phytopathology 53:881-882.

McSorley, R. and Gallaher, R.N. (1996). Effect of yard waste compost on nematode densities and maize yield. Suppl. J. Nematol. 28: 655-660.

Mian, I. H., and Rodriguez-Kabana, R. (1982).Survey of the nematicidal properties of some organic materials available in Alabama as amendments to soil for control of Meloidogyne arenaria. Nematropica 12 (2) :235-246.

Montasser, S.A.; Abd-El-Wahab. A.E.; Abd Elgawad, M.M.M.; Abd-El Khair, H.; Koura, Faika H. and Hammam, M.M.A. (2012). Role of some plant extracts and organic manures in controlling Tylenchulus semipenetrans Cobb in vitro and in vivo in citrus. J. Appl. Sci. Res. 8: (11): 5415-5424.

Morris, K.S; Horgan, F.G.; Downes, M. J. and Griffin, C.T. (2011). The effect of temperature on hatch and activity of second-stage juveniles of the root-knot nematode Meloidogyne minor, an emerging pest in north-west Europe. Nematology13(8): 985-993.

Nowak, A.; Bakuta, T.; Matusiak, K.; Galeckl, R.; Borowski, S. and Gutrowskg, B. (2017). Odorous compounds from poultry manure induce DNA damage, nuclear changes and decrease cell membrane integrity in chicken liver hepatocellular carcinoma cells. Int. J. Environ. Res. Public Health 14C, 933. doi: 10. 3390/ ijerph 14080933. www.mdpi.com/journal/ijerph.

Oka, Y. (2010). Mechanisms of nematode suppression by organic soil amendments review. Appl. Soil Ecol. 44:101-115.

Osunlola, O.S. and Fawole, B. (2015). Evaluation of animal dungs and organomineral fertilizer for the control of Meloidogyne incognita on sweet potato. Inter. J. Agron 5 pp. https: doi.org/10,115/2015/725363.

Renco, M. and Kovácik, P. (2012). Response of plant-parasitic and free-living soil nematodes to composted animal manure soil amendments. J. Nematol. 44: 329 336.

Riegel, C. and Noe, J.P. (2000). Chicken litter soil amendment effects on soil borne microbes and Meloidogyne incognita on cotton. Plant Dis. 84:1275 -1281.

Rodríguez-Kábana, R. (1986). Organic and inorganic nitrogen amendments to soil as nematode suppressants. J. Nematol. 18(2):129-34.

Sasser, J.N. (1989). Plant-parasitic nematodes: The farmer's hidden enemy. Raleigh, NC, USA, North Carolina State University, 115 pp. 
Siddiqi, M.R. (1986). Tylenchida, parasites of plants and insects. C.A.B. Commons. Inst. Parasit .; Slough, UK, 645 pp.

Sideman, B.; Majewski, C.; Haddad, Nada and Buob,T. (2013). Guidelines for using animal manures and manure-based composts in the garden. Fact sheet, UNH Cooperative Extension Programs, and Policies.

Tchounwou, P.B.; Ashour, B.A.; Young, G.M.; Ragheb, D.A.; Romeh, A.A.; Goma, E.; ElSheikh, S.; Lidell, F.P.; Ibitayo, O. and Assad, J.C. (2002). Health risk assessment of pesticides usage in Menia El-Kamh province of Sharkia governorate in Egypt. Int. J. Mol. Sci. 3 (10): 1082-1094.

Thoden, T.C.; Korthals, G.W. and Termorshuizen, A.J. (2011). Organic amendments and their influences on plant-parasitic and free-living nematodes: A promising method for nematode management. J. Nematol. 13:133-153.

Viaene, N.M. and Abawi, G.S. (1998). Fungi parasitic on juveniles and egg masses of Meloidogyne hapla in organic soils from New York. Suppl. J. Nematol. 30(4S):632-638.

Whitehead, A.G. (1998). Plant nematode control. CAB International, Wallingford, U.K., pp 384.

Wixted, D.J.; Lora, R. and Kotcon, J.P. (1987). Efficacy of ethoprop on potato and the potential for ground water contamination. J. Nematol. 19: 563-564.

Yang, Y.R.; Li, X.G.; Zhou, Z.G.; Zhang, T. L. and Wang, X. X. (2016). Differential responses of soil nematode community to pig manure application levels in Eerricacrisols Scientific Reports, http://dx.doi.org/10.1038/strep35334. 


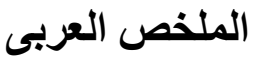

\section{Citrus reticulata (Blanco)تأثير بعض الأسمدة الحيو انية على مجتمعات النيماتودا في بساتين اليوسفي

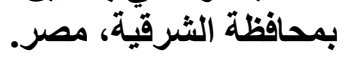

\author{
عمرو محمد المرزوقي ـ أحمد محمد الديب- ـ مصطفى النبوي محروس- رمضان محمد العشري \\ قسم وقاية النبات ـكلية الزراعة - جامعة الزقازيق
}

تم دراسة تأثير السماد الحيو اني لكل من الابقاروالخيول والديك الرومي بالمقارنة مع الأوكساميل على النيماتودا

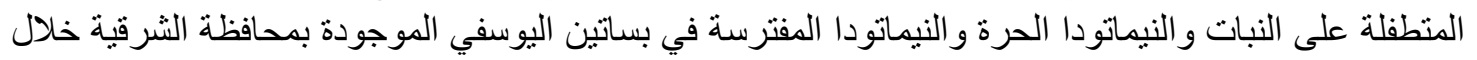

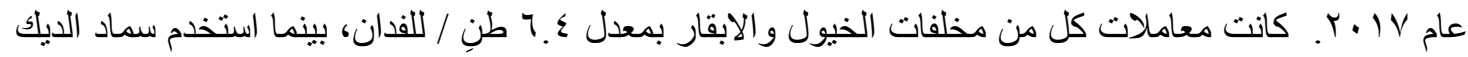

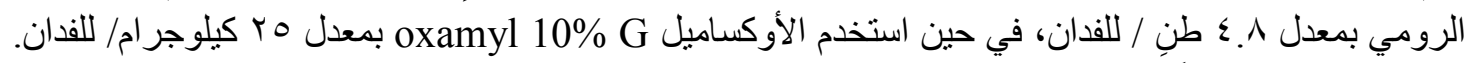

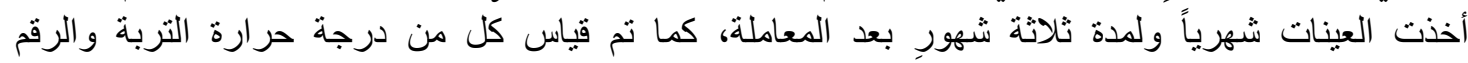

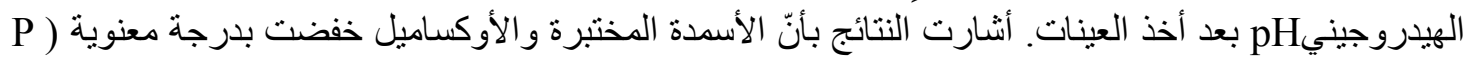

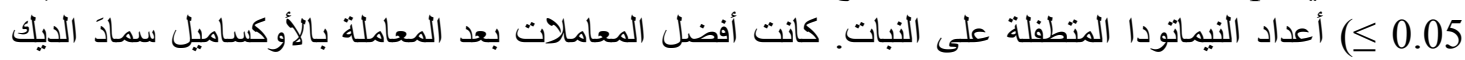

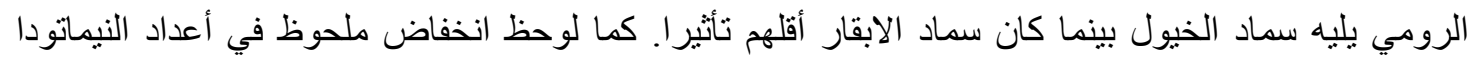

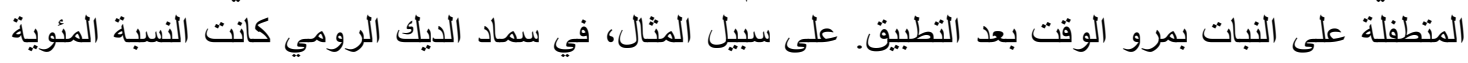

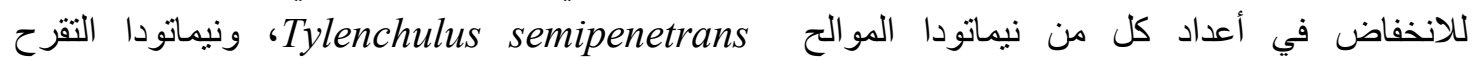

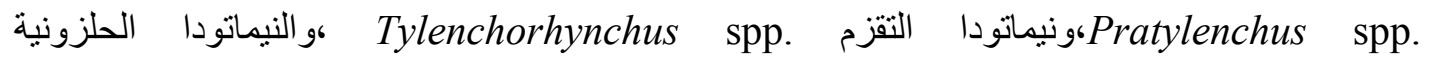

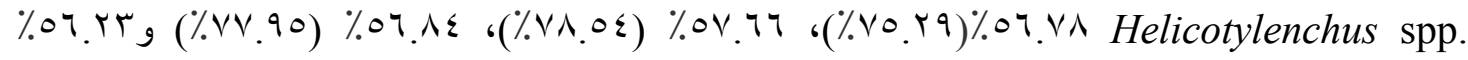

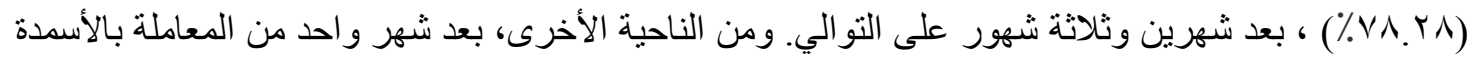

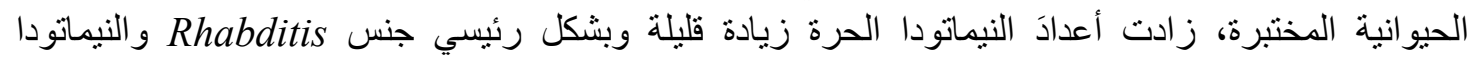

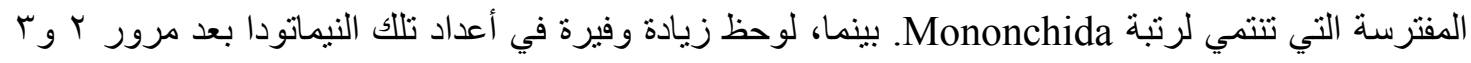

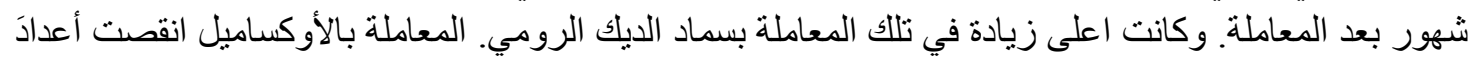

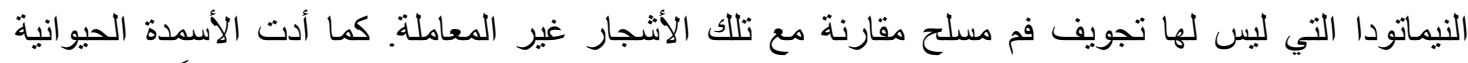

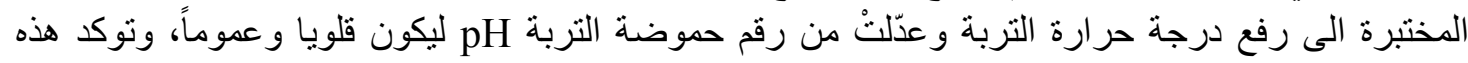

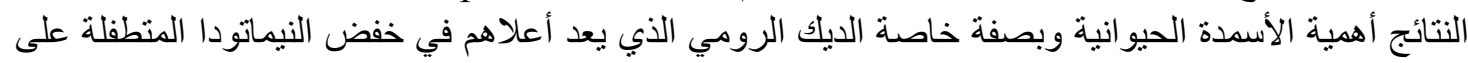

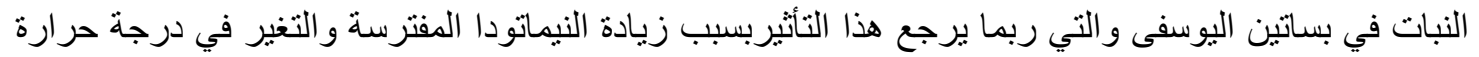
ورقم حموضة التربة. 